\title{
Hydrogen Fuel Cell Electric Vehicles
}

As nations around the world pursue a variety of sustainable transportation solutions, the hydrogen fuel cell electric vehicle (FCEV) presents a promising opportunity for American consumers and automakers.

FCEVs are important to our nation's future because they can:

- Play an important role in our portfolio of sustainable transportation options

- Provide a cost-competitive, appealing alternative for drivers

- Reduce dependence on imported oil and diversify energy sources for transportation

- Enable global economic leadership and job growth.

\section{Offering a Sustainable Transportation Option}

Americans have tremendous freedom to travel wherever and whenever they want. Ninety percent of travel in the United States is achieved by automobiles that refuel quickly at conveniently located stations and can go 300 to 400 miles between fill ups.

While no single alternative to today's cars and trucks can meet all our needs, FCEVs are poised to play an important role in America's portfolio of sustainable transportation options. FCEVs offer long ranges and fast refueling, and emit only water vapor.

\section{Bringing Cost-Competitive FCEVs and Hydrogen to Market}

Automakers around the world have made steady progress in reducing the cost and increasing the performance and durability of fuel cell propulsion systems. Despite the worst automotive recession in history, Daimler, Toyota, Honda,

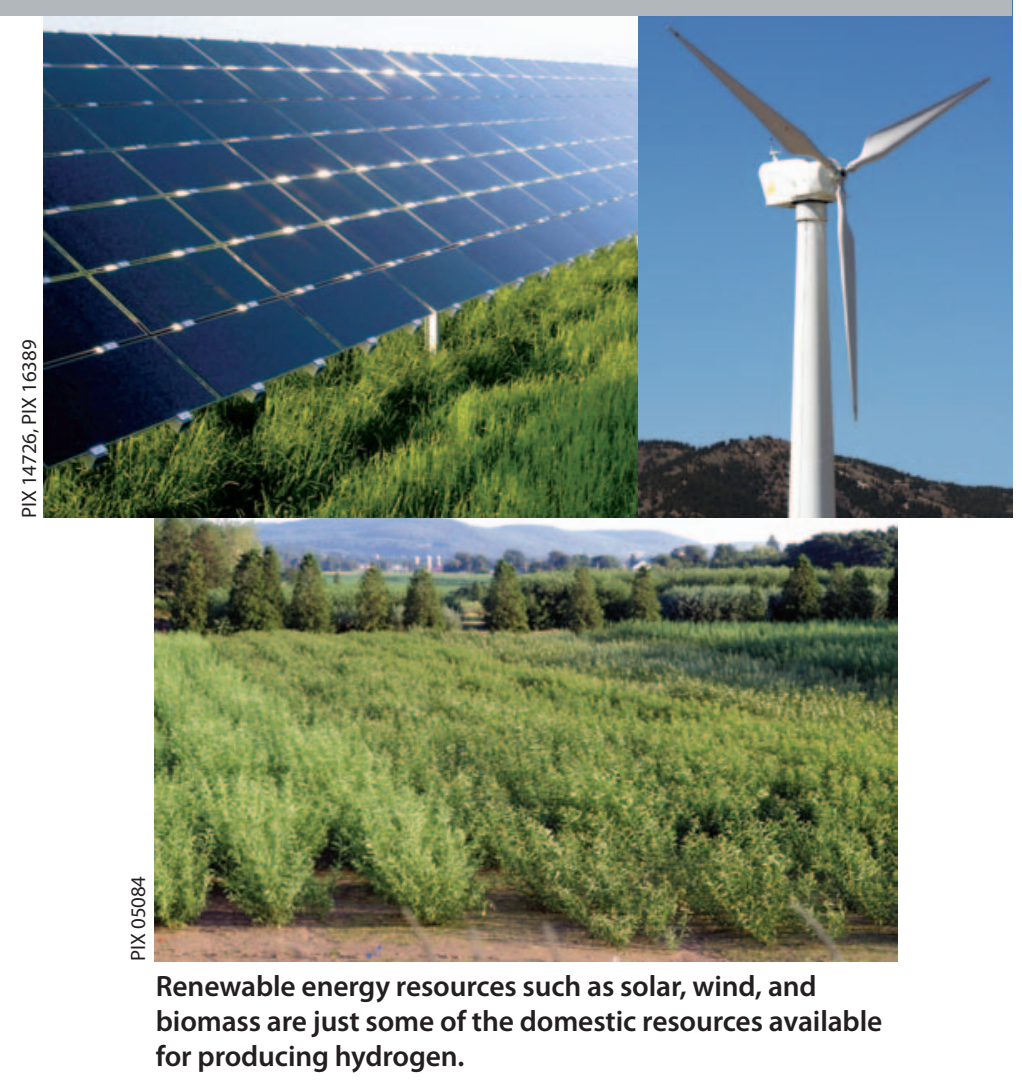

Hyundai, and General Motors (GM) continue to develop family-size FCEVs and plan to begin selling them by 2015.

FCEVs offer comparable range, performance, comfort, utility, and durability to today's cars and trucks. Ordinary Americans who have driven FCEVs say they're excited by the "real" driving experience and utility they provide, and confirm that conveniently available hydrogen fueling stations are essential to consumer acceptance.

Several studies from the U.S. Department of Energy (DOE) indicate that the cost of producing and distributing hydrogen could fall to a cost roughly equivalent to gasoline on a per-mile basis. These studies also conclude that a
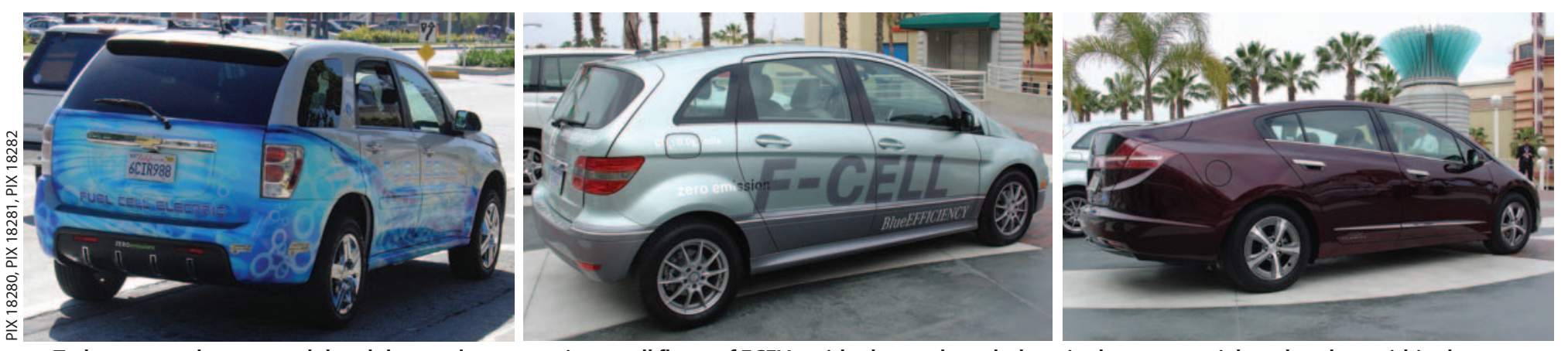

Today, automakers around the globe are demonstrating small fleets of FCEVs, with plans to launch them in the commercial marketplace within the next five years. 


\section{"Fuel cell electric vehicles offer Americans the} benefits of today's cars and trucks and promise to be cost competitive. Progress over the past 15 years has proven FCEVs can play an important role in the future U.S. transportation system."

Larry Burns, GM VP of R\&D and planning (retired)

hydrogen fueling infrastructure for FCEVs is economically viable, requiring an investment comparable to that of the Alaskan oil pipeline to make hydrogen available to $70 \%$ of Americans living in the 100 largest U.S. cities.

\section{Reducing Oil Imports and Greenhouse Gas Emissions}

Because hydrogen can be made from a variety of U.S. resources-wind, solar, biomass, geothermal, natural gas, coal, and nuclear energy-FCEVs reduce dependence on imported oil and diversify the energy sources used for transportation.

According to a Massachusetts Institute of Technology study, FCEVs have "the ultimate potential to dramatically decrease greenhouse gas emissions and reliance on petroleum"and they do so without requiring a change in driving behavior.

\section{Boosting the Economy and Creating Jobs}

The United States imports nearly two-thirds of its oil, accounting for $50 \%$ of our $\$ 49.9$ billion trade deficit. Replacing imported oil with domestically produced hydrogen from diverse resources would allow this outflow of dollars to stay in the U.S. economy and generate jobs throughout the nation. Hydrogen from renewable resources alone could be made in all 50 states, creating local jobs in every region of the country.

\section{Achieving International Competitiveness}

Global economic leadership is becoming increasingly dependent on global technology leadership, particularly in relation to energy and the environment. FCEVs provide the potential for the United States to lead the race for energy and environmental technology innovation, but the time to act is now. Germany, Japan, and Korea are making great strides in developing FCEVs and planning for additional fueling stations. To remain competitive in the global marketplace, the United States must make a significant commitment to the continued development of FCEVs and the supporting fueling infrastructure.

\section{What's Next?}

According to a recent news release from the National Research Council, "the public-private partnership to develop vehicles that require less petroleum-based fuel and emit fewer greenhouse gases should continue to include fuel cells and other hydrogen technologies in its research and development portfolio." This public-private partnership - the FreedomCAR and Fuel Partnership—is a research collaboration between DOE and the automotive and energy industries to develop affordable, clean, energy efficient cars and light trucks. While the FreedomCAR and Fuel Partnership has made great strides in reducing costs and advancing technology, additional research and development is crucial in order for the United States to reap the full and substantial benefits that FCEVs offer.

\section{How Do Fuel Cell Electric Vehicles Work?}

Hydrogen is delivered into the vehicle's onboard fuel tank and fed to the fuel cell. The fuel cell converts the chemical energy in hydrogen to electricity, which powers the vehicle.

\section{Learn More}

Visit the National Renewable Energy Laboratory (NREL) Hydrogen and Fuel Cells Research Web site at www.nrel. gov/hydrogen or call the NREL Hydrogen Technologies and Systems Center at 303-275-3852.

\section{References}

Kromer, M.; Heywood, J. (2007). Electric Powertrains: Opportunities and Challenges in the U.S. Light-Duty Vehicle Fleet. LFEE 2007-03 RP. Cambridge, MA: Sloan Automotive Laboratory, Laboratory for Energy and the Environment, Massachusetts Institute of Technology.

The National Academies. (2010). News from the National Academies: Clean Vehicle Research Initiative Should Continue to Include Hydrogen Technologies along with Advanced Combustion Engines and Electric Vehicles. www8.nationalacademies.org/onpinews/newsitem. aspx?RecordID=12939. Accessed September 2, 2010.

U.S. Census Bureau. (2010). “U.S. International Trade in Goods and Services Highlights." www.census.gov/indicator/www/ ustrade.html. Accessed August 31, 2010. 